\title{
Ready for university? A cross-national study of students' perceived preparedness for university
}

\author{
Ellen P. W. A. Jansen · Jacques van der Meer
}

Published online: 15 November 2011

(C) The Author(s) 2011. This article is published with open access at Springerlink.com

\begin{abstract}
Students' preparedness for higher education is seen as one of the main factors affecting first-year attrition or study success. In this paper we report on a cross-national study in which students' preparedness for university was measured before students commenced their study at a university in New Zealand or in the Netherlands. This cross-national project provided a unique opportunity to compare students' perceptions of readiness for university where students are prepared for higher education in quite different secondary school systems. Departing from a transition framework, and comparing the results in both countries using logistic regression techniques to investigate which aspects of readiness could predict perceived preparedness, we discovered similarities in as well as differences between students' perceived readiness for university study. It could be argued that differences are caused by the different educational systems at secondary level. However, overall we can conclude that, in spite of differences between the educational systems in the two countries, many differences were not remarkable or very significant. This has clear implications for how we view the relative importance of secondary school preparation and tertiary induction. We can expect greater benefit from implementing first-year pedagogical practices in universities that would assist students to develop their academic skills, than from demanding that high schools prepare students better.
\end{abstract}

Keywords Readiness · Transition · First-year experience $\cdot$ Cross-national comparisons

E. P. W. A. Jansen ( $\square)$

University of Groningen, P.O. Box 800, 9700 AV Groningen, The Netherlands

e-mail: e.p.w.a.jansen@rug.nl

J. van der Meer

College of Education, The University of Otago, P.O. Box 56, Dunedin, New Zealand

e-mail: Jacques.vandermeer@otago.ac.nz 


\section{Introduction}

There is global demand for a highly educated workforce. It is argued that nations need well-educated citizens not only for technological advancement, but also for social and cultural advancement (Lisbon European Council 2000). Although widening participation is high on the agenda for many countries, increased participation does not guarantee increased completion rates. The remarks made by the OECD Secretary-General at the presentation of Education at a Glance 2008 (OECD 2008), make it clear that high school graduation for the majority of schoolage students is becoming the norm in most OECD countries. Most of these students aim to pursue tertiary education. However, dropout rates in higher education are very high. The OECD reports that approximately one third of students in higher education in the OECD countries do not complete their studies (OECD 2008).

Most research on attrition focuses on students' experiences in the first year in higher education (Krause 2005; McInnis and James 2004; Yorke 1999). In many studies it has been demonstrated that the first-year experience is indicative of success in continuing years (Hurtado et al. 2007; Jansen and Bruinsma 2005; Keup and Stolzenberg 2004; Nora et al. 2005). There is all the more reason, therefore, for institutions in higher education to ensure and enhance students' first-year experience. Internationally there is a wide body of research on factors that influence students' decision to drop out in the first year (Braxton 2000; Harvey et al. 2006; Krause 2005; van Os 2008; Yorke and Longden 2004). Although the context differs between countries, institutions and even disciplines, there appear to be common factors related to the transition to higher education.

The notion of 'transition' can be considered in different ways. Generally it refers to a period of adjustment in order to enter into a more stable phase (see for example Nicholson 1999). It can also be considered as a recurrent, circular event. Ross and Gray (2005), for example, refer to second chance education as a fluid state, a journey which starts and ends and starts again. All transition moments provide students with a degree of uncertainty (Gurin et al. 2002). Studies on students' transition and first-year experience show four main groups of reasons for students to drop out (Yorke and Longden 2004): unsatisfactory experience, inability to cope with academic demands, wrong choice of course, and a range of personal factors like financial problems, illness, and family circumstances. Preparedness for academic education is one of the most important factors for success at university. It can be expected that students who feel better prepared for university will have less trouble with the transition.

Research findings related to the importance of preparedness are in line with theories related to self-efficacy (Bandura 1997; Pajares 1996). In these theories it is assumed that self-confidence in being able to accomplish a specific task is predictive of performance. Quinn and Hemmings (1999) in a study at one Australian university, demonstrated that self-efficacy was the strongest predictor of persistence in the course they studied. Pajares (1996) has argued that the construct of selfefficacy needs to be measured at a task-specific level. Weiner's attribution theory (1985) suggests that students who feel better prepared regarding certain academic skills that are seen as important for success at university, can be more motivated 
than students who consider themselves less ready for the new situation. The notion of academic preparedness relates closely to the construct of 'academic integration', which is an important variable in transition studies that relates to the so-called 'interaction models' (Pascarella et al. 1983; Tinto 1987). Although we consider social integration to be important, it is difficult to measure readiness for social integration.

Students' expectations regarding higher education can also determine how they experience their first year at university and, consequently, whether they stay or leave (McInnis et al. 2000; Smith and Wertlieb 2005). In our research project we tried to ascertain students' expectations with regard to, for instance, induction to academic skills, help finding, and expected similarity or difference with high school. Watson et al. (2002) reported medium levels of agreement in being confident to work independently or with other people, and low levels of understanding how to achieve successful study outcomes, as well as low levels of agreement about time management. University teachers expect students who start their study to have skills such as processing lots of information, writing essays, and independent learning (Smith and Wertlieb 2005). Research findings by one of the authors of this paper (van der Meer 2008) too, suggested that many university teachers expected students to have a range of skills that were distinctly different from those developed at high school. Barrie $(2006,2007)$ in his study refers to teachers' expectations of students' 'precursor abilities': i.e., skills that students are assumed to have before they start higher education. According to Taylor and Bedford (2004) a mismatch between student and university expectations is one of the main reasons for non-completion. In their research they found that staff presumed the level of preparedness, besides levels of motivation and ability, to be the significant factor for drop-outs. Recent reforms of pedagogical practices in a part of the Dutch secondary education system, sought to address students' academic readiness and skills that were assumed to be necessary for successful study in higher education (Tweede Fase Adviespunt 2005).

In this article we report on a study in which we investigated students' perceived preparedness for university in a cross-national context. The Readiness and Expectations Questionnaire (REQ), developed in a collaborative project between the University of Otago and the University of Groningen (Jansen and van der Meer 2007; van der Meer and Jansen 2008), concerns readiness in the fields of time management, written communication, group work, information processing, ICT skills, and verbal communication. We aimed to explore similarities and differences in perceived preparedness between students in two countries with distinctly different high school systems. In contrast with many studies in which factors on drop-out or study success are investigated during or after the first year, we carried out a survey among students before they started their formal academic studies.

We also aimed to explore whether transition to university could be seen as a more generalisable issue, in which students in different countries experience more or less similar academic challenges. Research and literature on the first-year experience is dominated by English speaking countries such as Australia, the United Kingdom, and the United States. Instruments and results are often translated to other countries that have quite different educational systems. This collaborative study between New Zealand and the Netherlands, with both authors being bi-lingual, offered a unique 
opportunity to investigate whether it was possible to use the same instrument in the two countries. The two universities were similar in a number of respects: both universities are research intensive, are among the oldest university establishments in their respective country, are similar in size (about 20,000-25,000 students) and offer a broad range of degree programmes. About $80 \%$ of their first-year populations enter university with a high school qualification. The high school systems in the Netherlands and New Zealand, however, are quite different: a differentiated system with specific high schools preparing students for (research) university level studies in the Netherlands versus an undifferentiated high school system in New Zealand. This means that Dutch students who spend six years of high school in the Voorbereidend Wetenschappelijk Onderwijs schools (translation: Schools for preparatory university education) could reasonably be expected to feel more ready to enter university after six years than New Zealand students who follow a broadbased general secondary education that prepares them for a range of postcompulsory education options.

In summary, the research approach of our (ongoing) project differs methodologically in two main aspects from many other first-year related studies. Firstly, the study seeks to assess students' perceptions of their readiness before they start their university studies. Secondly, by comparing results in two different countries with distinctively different high school systems, we seek to establish whether students' self-perceived readiness is a clear function of university preparation provided by high schools, or whether students' perceptions may have more to do with their expectations of entering a new educational environment where they have to learn new skills. In the coming years we hope to be able to answer some of these questions.

\section{Research questions}

In this article we address three research questions:

1. Do students from the two countries differ in their overall self-perceived preparedness and in their self-estimated chances of success?

2. Can we establish differences on aspects of readiness between the two groups of students?

3. To what extent can we explain the perceived preparedness by readiness and self-estimated chances of success? Which factors differ and which factors can be considered to have a similar effect on perceived preparedness in the two countries?

\section{Research design}

\section{Instrument}

The Readiness and Expectations Questionnaire (REQ) was developed through an iterative process of trialling questions in the broad academic skills areas of our 
interest. Because of the different starting dates for the academic years in the northern and southern hemispheres, we were able to speed up the process of trialling questions: we had two opportunities to access intending first-year students, rather than just one. The first two rounds were in July/August 2006 (the Netherlands) and February/March 2007 (New Zealand). The REQ was administered before the start of the academic year of the two respective universities. In the Netherlands a combined paper and pencil, and online survey was used; for logistical reasons only an online survey was administered in New Zealand.

The REQ contains five-point Likert-type items (strongly disagree-strongly agree). After the first administration of the REQ we performed a factor analysis with varimax rotation. This revealed six factors, which could be interpreted as: time management, written communication, group work, information processing, ICT, and verbal communication (Jansen and van der Meer 2007; van der Meer and Jansen 2008). Based on this factor analysis we eliminated some questions, and rephrased others for the second administration. Further adjustments were made after this. The results in this article are from the 2007 round in the Netherlands, and the 2008 round in New Zealand.

The iterative development of the REQ has resulted in factors with reliable scale scores (see Appendix 1 for the items). The scale scores were calculated by adding the item scores and dividing these by the number of items (unweighted). As outcome variable we asked students to give an overall evaluation of how well they felt that high school or other experiences prepared them for university; we also asked them to give an estimation of how successful they expected to be in the first year. Lastly, students were asked to provide some personal details such as age, gender, and motivation for the choice of subject.

Analysis

The data were analysed using SPSS-14. Differences in perceived preparedness and the self-estimation of study success between the two sub-samples were investigated using a $\chi^{2}$-test. The contribution of the different readiness aspects in explaining students' perceived readiness was attained by logistic regression analysis. Logistic regression techniques were used instead of, for example, discriminant analysis because the assumption of multivariate normality could be violated and because of the use of a dichotomous variable ('well prepared' vs. 'ill prepared'). Press and Wilson (1978) recommend logistic regression in such cases.

\section{Results}

\section{Response}

The sample consisted of 1,948 students, 1,490 from the University of Groningen and 458 from the University of Otago. The percentage of students of 18 years or younger was higher in the New Zealand sample, the percentages of female students 
Table 1 Student characteristics

\begin{tabular}{lll}
\hline & $\begin{array}{l}\text { University of } \\
\text { Otago }\end{array}$ & $\begin{array}{l}\text { University of } \\
\text { Groningen }\end{array}$ \\
\hline$\%$ 18 years or younger & 75.2 & 61.0 \\
$\%$ female & 61.8 & 63.0 \\
$\%$ high school & 80.6 & 81.6 \\
\hline
\end{tabular}

were about the same, as were the percentages of students with a high school qualification (Table 1).

Difference in overall preparedness and self-estimated success

There is a significant difference between the two sub-samples regarding the respondents' self-perceived preparedness by high school $\left(\chi^{2}=20.44\right.$, $\mathrm{df}=2$, $p<0.001)$. There is a significant difference as well between the two samples with regard to the variable 'self-estimation of first year success'; the Otago students felt more confident than the Groningen students $\left(\chi^{2}=12.52\right.$, df $\left.=2, p<0.002\right)$ (Table 2).

\section{REQ-characteristics}

Table 3 below shows the scale characteristics of the REQ-readiness scales. All scales have a sufficient reliability. On four of the six readiness scales there was a significant difference in mean scores between the two samples (see last column in Table 3). The Dutch students felt better prepared in time management, written

Table 2 Overall self-reported preparedness and self-estimated study success

\begin{tabular}{lll}
\hline & $\begin{array}{l}\text { University } \\
\text { of Otago }\end{array}$ & $\begin{array}{l}\text { University of } \\
\text { Groningen }\end{array}$ \\
\hline \% well prepared by high school & 52.2 & 58.6 \\
\% ill-prepared by high school & 23.6 & 14.4 \\
\% high self-estimation of & 73.1 & 61.1 \\
\begin{tabular}{l} 
first-year success \\
\hline
\end{tabular}
\end{tabular}

Table 3 Scale characteristics

\begin{tabular}{llllllll}
\hline Scales & $\begin{array}{l}\text { Number } \\
\text { of items }\end{array}$ & $\alpha$ & $\begin{array}{l}\text { Mean } \\
\text { UoO }\end{array}$ & SD & $\begin{array}{l}\text { Mean } \\
\text { UoG }\end{array}$ & SD & Significance \\
\hline Readiness & & & & & & & \\
$\quad$ Time management & 4 & 0.71 & 3.64 & 0.74 & 3.73 & 0.73 & 0.05 \\
Written communication & 4 & 0.86 & 3.39 & 0.89 & 3.72 & 0.79 & 0.00 \\
Group work & 4 & 0.80 & 3.62 & 0.86 & 3.52 & 0.78 & 0.05 \\
Info-processing & 4 & 0.71 & 3.56 & 0.75 & 3.68 & 0.66 & 0.00 \\
ICT & 3 & 0.79 & 4.29 & 0.85 & 4.26 & 0.70 & n.s. \\
Verbal communication & 2 & 0.63 & 3.47 & 0.95 & 3.51 & 0.93 & n.s. \\
\hline
\end{tabular}


communication, and information processing, while the New Zealand students felt better prepared for group work tasks. The skewness of the distribution of the scales is negative for all the scales, implying a longer tail at the left side of the distribution and most values being situated at the right side of the mean.

\section{Readiness and perceived preparedness}

In this section we address the question, what is the relation between students' selfreported readiness in the different fields we discerned and their perceived preparedness before starting their studies? Table 4 displays the results of the logistic regression analysis; the dependent variable was well-prepared by high school or ill-prepared by high school. We used a cut-off value of 0.70 because in the dichotomous variable well-prepared or ill-prepared, about $70 \%$ of the students indicated feeling well prepared. The scores on the readiness scales were centred by subtracting the sample mode of the individual score. In the first model we only entered the scores on the centred readiness scales.

In this model all but one readiness scale (ICT) significantly affected the chances of feeling well-prepared, although the effect of verbal communication was negative. Because we had already analysed differences between Otago and Groningen on four scales (see Table 3), in Model B we added four interaction effects (institution $\times$ scale). Comparing the $-2 \log$ likelihood of the first model with the second model, a significant difference was found $\left(\chi^{2}=11.30\right.$, df $\left.=4, p<0.05\right)$. In this model $80.4 \%$ was predicted correctly.

Table 4 Parameter estimation logistic regression: perceived well-preparedness

\begin{tabular}{|c|c|c|c|c|}
\hline & \multicolumn{2}{|l|}{ Model A } & \multicolumn{2}{|l|}{ Model B } \\
\hline & $\mathrm{B}$ & SE & B & SE \\
\hline Constant & 1.505 & 0.176 & 1.840 & 0.251 \\
\hline Institution ( $1=$ Groningen $)$ & 0.280 & 0.178 & -0.089 & 0.269 \\
\hline $\mathrm{R}$ time management & $0.425 * *$ & 0.116 & 0.187 & 0.298 \\
\hline $\mathrm{R}$ written communication & $0.404 * *$ & 0.109 & $0.768 * *$ & 0.239 \\
\hline $\mathrm{R}$ group work & $0.285 * *$ & 0.100 & 0.174 & 0.209 \\
\hline $\mathrm{R}$ information processing & $0.454 * *$ & 0.137 & $0.979 * *$ & 0.331 \\
\hline R ICT & -0.028 & 0.106 & -0.003 & 0.107 \\
\hline $\mathrm{R}$ verbal communication & $-0.228 * *$ & 0.090 & $-0.238 * *$ & 0.092 \\
\hline $\mathrm{R}$ time $\times$ institution & & & 0.270 & 0.324 \\
\hline $\mathrm{R}$ write $\times$ institution & & & -0.485 & 0.267 \\
\hline $\mathrm{R}$ group $\times$ institution & & & 0.136 & 0.231 \\
\hline $\mathrm{R}$ infopro $\times$ institution & & & -0.660 & 0.361 \\
\hline Nagelkerke $\mathrm{R}^{2}$ & \multicolumn{2}{|l|}{0.159} & \multicolumn{2}{|l|}{0.172} \\
\hline Hosmer-Lemeshow goodness-of-fit & \multicolumn{2}{|c|}{$\chi^{2}=11.69, \mathrm{df}=8, p=0.16$} & \multicolumn{2}{|c|}{$\chi^{2}=6.74, \mathrm{df}=8, p=0.56$} \\
\hline
\end{tabular}

** Significant $p<0.01$ 
In a logistic regression analysis we do not have a definition of the proportion of variance explained, similar to linear models. However, there are pseudo- $\mathrm{R}^{2}$ measures such as Nagelkerke's $\mathrm{R}^{2}$; this is not completely comparable with $\mathrm{R}^{2}$ in linear regression models (Peng et al. 2002). In general, the pseudo $\mathrm{R}^{2}$ have rather low values (Sieben 2001). The goodness-of-fit test (Hosmer-Lemeshow) yielded a $\chi^{2}(8)$ of 6.74 and was insignificant, which points to a good fit of Model B to the data.

Model $\mathrm{B}$ in Table 4 reveals a positive significant effect regarding perceived readiness in the fields of written communication and information processing, and a negative significant effect from verbal communication. Although not significant at 0.05 level, the interaction effects between institution and readiness for written communication and readiness for information processing (significant at 0.07 and 0.06 levels respectively) do indicate differences in the extent to which self-reported readiness affects the perceived preparedness. To analyse this in more detail, separate logistic regression analyses were carried out for Groningen and Otago, to get more information on the relative contribution of the different readiness aspects to the perceived preparedness of students in the two institutions.

Table 5 shows the results of the logistic regression analysis expressed in terms of the odds ratio regarding perceived preparedness (well-prepared, ill-prepared) for Groningen and Otago students.

The odds ratio for time management indicates that the chance to feel wellprepared was 1.597 higher for a Groningen student, with a one point higher score on the readiness for time management scale. For Otago students that was 1.230. An odds ratio below 1 means a negative effect; for example, Groningen students who score one point higher on verbal communication have 0.784 less chance to feel well prepared. The results suggest significant effects for Groningen on all the readiness scales, except for ICT, as in Model A in Table 4. For Otago, however, only written communication and information processing seem to be significant.

Table 5 indicates that the odds ratio for verbal communication is about the same for Otago and Groningen. The difference in sample size between the two samples can be considered as an explanation for the fact that perceived readiness on verbal communication is statistically significant for the Dutch sample and not for the New

Table 5 Results logistic regression analysis on preparedness expressed in the odds ratio

\begin{tabular}{|c|c|c|c|c|}
\hline & \multicolumn{2}{|c|}{ Groningen } & \multicolumn{2}{|l|}{ Otago } \\
\hline & $\begin{array}{l}\text { Odds } \\
\text { ratio }\end{array}$ & $95 \% \mathrm{CI}$ & $\begin{array}{l}\text { Odds } \\
\text { ratio }\end{array}$ & $95 \% \mathrm{CI}$ \\
\hline $\mathrm{R}$ time management & 1.579 & $1.232-2.024$ & 1.230 & $0.682-2.218$ \\
\hline $\begin{array}{l}\mathrm{R} \text { written } \\
\text { communication }\end{array}$ & 1.351 & $1.057-1.727$ & 2.138 & $1.322-3.458$ \\
\hline $\mathrm{R}$ group work & 1.370 & $1.102-1.705$ & 1.132 & $0.684-1.872$ \\
\hline $\begin{array}{l}\mathrm{R} \text { information } \\
\text { processing }\end{array}$ & 1.392 & $1.032-1.877$ & 2.511 & $1.293-4.877$ \\
\hline R ICT & 0.941 & $0.738-1.201$ & 1.185 & $0.778-1.806$ \\
\hline $\begin{array}{l}\mathrm{R} \text { verbal } \\
\text { communication }\end{array}$ & 0.784 & $0.645-0.952$ & 0.803 & $0.497-1.297$ \\
\hline
\end{tabular}


Zealand sample. The odds ratio can be seen as an effect size for the different variables on perceived preparedness. The closer the odds ratio is to one, the smaller the effect (Tabachnick and Fidell 2007). As a rule of thumb, analogous to Cohen's $d$, effect sizes below 1.3 are considered small, those between 1.3 and 1.8 medium, and those above 1.8 large. However, Rosenthal (1996, cited in Allan and Le 2007) contends that it is rather dangerous to use a qualitative description of the effect size as a universal criterion because, for instance, effect sizes in the social and behavioural sciences tend not to be as large as in the natural sciences. Rosenthal suggests that the interpretation of effect sizes should be adjusted by subfield and context. With this in mind, we can describe the effects of readiness in the area of written communication and information processing as large in the Otago sample, and all the effects in the Groningen sample as medium to small.

Introducing the variable 'self-estimation of success chance' in the logistic regression did not reveal different outcomes regarding the contribution of the readiness scales. This variable correlates significantly with all the readiness scales at 0.01 level, except for the group work scale, which correlates at 0.05 level. As expected, this variable showed a significant effect in the regression analysis, but the other effects remained (see Appendix 2). Because the readiness scales provide more specific information than the estimated chance of success, which can be seen as a measurement of self-efficacy (partly built around different aspects of readiness), we will only discuss the results of the analysis without the self-estimation of chances of success.

\section{Discussion}

Transition to university is a process that involves uncertainties. We assumed that these uncertainties would play a role in all countries. Students' perceived preparedness for university is expected to be a motivational factor for good performance. Bandura (1997) in his theory of self-efficacy contends that expectations of efficacy, i.e. self-confidence regarding ability to accomplish particular tasks, are predictors for performance. In our study we used six scales to elicit students' expectations of efficacy regarding a range of academic skills that students are generally expected to master in order to be successful in the first year of university. However, it is clear from the literature that different academic teachers have different understandings as to the level at which first-year students are expected to master these skills (Barrie 2006, 2007; Smith and Wertlieb 2005). Barrie refers to these expected skills at entry as 'precursory abilities'.

Our first research question addressed differences between students from the two countries on overall self-perceived preparedness and self-estimated chance for success. We found a significant difference between the Groningen and Otago students in the percentages of students who felt well-prepared or ill-prepared by high school. A higher percentage of Groningen students felt well-prepared and a lower percentage felt ill-prepared by secondary education. The percentage of students who were 'uncertain' about their level of preparedness, was about the same for both countries. In the Netherlands, specific schools in the secondary education system are 
particularly set up to prepare students for university studies. It could be expected, therefore, that these students would report higher levels of general preparedness than New Zealand students who come through an undifferentiated system. Interestingly, when students were asked to estimate their chances of success in the first year, New Zealand students expressed more confidence in being able to complete their first year successfully: $73 \%$ of the Otago students versus $61 \%$ of the Groningen students. This is not easy to interpret. It could be suggested that the Groningen students, because of their specific secondary schools, are more realistic about university standards and requirements. It could also suggest that Otago students are more determined and motivated to pass their first-year courses. Close to $70 \%$ of students who come to the University of Otago come from other parts of New Zealand. Many of those have made a choice not to attend a more local university; some students will have chosen Otago because of some courses that are only offered at Otago.

Significant differences between the Otago and Groningen students were found in the areas of time management, information processing, written communication, and group work. Regarding the first three areas, the Dutch students scored significantly higher; in the fourth area the Otago students scored higher. This last outcome is surprising. The changed pedagogical approaches to high school education in the university preparation schools have resulted in an increased emphasis on group work, research and writing tasks. van der Meer (2008) in his research found that many firstyear students at Otago experienced considerable challenges in assignments that involved a high degree of group work. Although the cohort in that research was different from that surveyed for the REQ project, the higher confidence expressed by Otago students could be interpreted as a function of the particular characteristics of Otago students, rather than actual levels of preparedness.

The last research question dealt with the possibility of explaining perceived preparedness by the different aspects of readiness. A logistic regression analysis for the complete sample revealed that, apart from readiness on ICT skills, all other scales were significant contributors to students' self-assessment of being well-prepared. The negative effect of verbal communication is surprising; it was expected that students who felt confident in small group discussion and who felt good at presenting, should feel better prepared. However, while we know that female students perform better in verbal communication assignments than men, female students are also known to report lower self-confidence. That could be an explanation for this negative effect. Another explanation could be the fact that the verbal communication scale exists of only two items; this makes it somewhat less reliable.

Interaction effects (although significant at 0.06 and 0.07 level) did point at differences between the two sub-samples. Two separate logistic regression analyses showed a common effect caused by written communication and information processing for both sub-samples. For the Dutch sample, additional effects were found for time management and group work (positively), and verbal communication (negatively).

Who prepares students for academic study: high school or university?

The theoretical construct of self-efficacy (Bandura 1997) is one explanation why feeling well-prepared positively contributes to success in the first year. This 
perceived preparedness is affected by the feeling of having a reasonable mastery of different types of skills, as could be concluded from our findings. Ozga and Sukhnandan (1998) in their study, contend that a lack of preparedness is one of the main reasons for students dropping out.

The question can therefore be asked whether high schools should better prepare students for university studies? As mentioned earlier, reforms in the Netherlands high school system were trying to achieve just that. The intended purpose was to make the transition to higher education easier and to reduce the first-year attrition caused by difficult adjustment to academic requirements. Several subsequent evaluation studies have demonstrated that students who have come through the new high school system appear to have mastered certain skills better, such as the ability to work in groups, but that this happened at the expense of subject knowledge. Furthermore, although attrition rates decreased somewhat, students' overall time to graduation (study progress) did not improve (Tweede Fase Adviespunt 2005). This rather negative result of the educational reforms could lead to the question, what else high schools could possibly do to prepare students better?

Consideration could be given to other transition or bridging solutions. Smith and Wertlieb (2005) refer to the high school-college disconnect. They assume that better cooperation between high schools and institutes for higher education could benefit first-year students. College preparatory programmes or outreach programmes could fill the gap between high school and university. In the Netherlands, programmes of this kind have been developed over the past decades. The number of students who can or do enrol in those activities is rather small, because those activities are not a part of the regular high school curriculum. These types of activities could play a role in giving future students a more realistic picture of university. This is especially important for students whose families do not have experience in higher education. Boyd et al. (2001) in a research project in New Zealand reported that students from higher decile schools (schools who draw students from higher social economic areas) got their information regarding higher education mostly from their families, while students from lower decile schools were relying on information from their schools.

Alternatively, the question can be asked whether the onus of preparing students for academic work should be on the universities rather than high schools. Rather than reforming secondary education, it could be suggested that the first year in higher education should be reformed. Increasingly, well-known researchers in the area of retention studies suggest that universities should play an active role in reducing attrition by adapting institutional and pedagogical practices (Braxton et al. 2007; Kuh et al. 2008; Tinto 2006). If seemingly better preparation of Dutch students does not necessarily result in distinctively increased self-efficacy prior to entry, our focus should be more on increasing students' self-efficacy in the first year. On a practical level this could include a scaffolded approach to developing certain academic skills and early opportunities to experience success.

One focus of change by universities could be pedagogical practices in the first year. This change could be conceptualised as a move towards what Kift (2008) refers to as 'Transition Pedagogy'. Kift (2008) contends that the first-year experience is 'everybody's business'. She translates transition pedagogy in First 
Year Curriculum Principles for institutional learning and teaching leaders, program coordinators, and of course first year teachers. Central to first-year teaching practices should be the embedding of a range of academic skills within courses, rather than teaching those skills separately from courses. Embedded programmes assume that all students benefit from intentional course-specific induction into the discourse conventions of different disciplines (Chanock 2004). However, this is probably one of the least often implemented models. Embedding is being held up as the 'ideal' model (Jones et al. 2001), and many university learning support units are moving from de-contextualised, generic courses to discipline-specific, contextualised teaching (James et al. 2003). In fact, one of the models is called the IDEALL model (Skillen et al. 1998), the 'Integrated Development of English Language and Academic Literacy and Learning' (IDEALL). Its philosophy is that all new students on entering university need generic academic skills as well as skills for a specific discipline. This, they say, circumvents the slow process of 'osmosis'. Other pedagogical practices to introduce first-year students to academic skills could be through the use of peer-learning initiatives (van der Meer and Scott 2008).

There is clear evidence of a recognition that the sharing of good practices in developing transition pedagogies is important. National initiatives can be seen in various countries, for example, in Australia in the framework of the Australian Learning and Teaching Council (see e.g. Kift and Field 2009), in the Netherlands, with conferences organised by the Dutch Associations of Universities, in the United Kingdom, in the Centers for Excellence in Teaching and Learning of the Higher Education Academy, and in New Zealand, in the establishment of Ako Aotearoa. These initiatives hopefully will contribute to enhancement of the first-year experience, to the reduction of attrition, and to the improvement of study success.

\section{Concluding remarks}

Our intention in this paper was to take a closer look at different aspects of students' self-perceived readiness regarding particular academic skills in relation to selfperceived overall preparedness. We are aware that there are several other factors influencing this preparedness, that have not been taken into account. For example, students' pre-university achievements, gender, and field of study can affect students' perception of being ready for university. We are also aware that the sample in our study was only drawn from students of two universities. Although we do not have indications that our two universities are very exceptional in our respective countries, we are cautious about the generalisability of our results.

Overall we can conclude that, in spite of differences between the educational systems in the two countries, many differences were not remarkable nor very significant. Changes to pedagogical practices in Dutch high schools also did not show the hoped-for effect. A greater focus on first-year pedagogical practices in universities, however, may be what would assist students to develop the academic skills that universities look for and that could contribute to first-year students' success and retention. 
Open Access This article is distributed under the terms of the Creative Commons Attribution Noncommercial License which permits any noncommercial use, distribution, and reproduction in any medium, provided the original author(s) and source are credited.

\section{Appendix 1: Items for the readiness scales}

\section{Time-management readiness}

74. I am good at planning and organising my study

77. My previous experiences prepared me well to keep up with lots of readings

84. Prior to coming to university I found it easy to keep up with tasks/assignments

85. I am good at working independently

\section{Written communication}

76. I can independently write a short report

79. I have been taught how to write essays

90. I am confident at writing essays

105. I have been taught how to write short reports

Group work

82. I have been taught how to work in small groups

100. I am confident working in small groups

101. Before coming to university I worked a lot in groups

110. I am confident working with other people in a group

\section{Information processing}

75. I find it easy to listen and make notes at the same time

92. I am confident in identifying the main ideas or main points in a text

99. I am confident writing a summary from the main points in a text or book

108. I am confident collecting and selecting information for assignments/projects

\section{$I C T$}

98. I am comfortable using computers for a range of tasks

104. I am confident using the internet to find information for assignments/projects

112. I have not used computers very much before (R)

\section{Verbal communication}

86. I am good at presenting verbal information

106. I am confident in discussing in small groups

\section{Appendix 2}

See Table 6. 
Table 6 Results of logistic regression analysis on preparedness expressed in the odds ratio, including self-estimation of chance for success

\begin{tabular}{|c|c|c|c|c|}
\hline & \multicolumn{2}{|l|}{ Groningen } & \multicolumn{2}{|l|}{ Otago } \\
\hline & Odds ratio & $95 \% \mathrm{CI}$ & Odds ratio & $95 \% \mathrm{CI}$ \\
\hline Self-estimation of success chance & 1.874 & $1.454-2.414$ & 1.787 & $1.171-2.727$ \\
\hline $\mathrm{R}$ time management & 1.370 & $1.051-1.787$ & 1.136 & $0.622-2.076$ \\
\hline $\mathrm{R}$ written communication & 1.312 & $1.012-1.701$ & 2.154 & $1.312-3.535$ \\
\hline $\mathrm{R}$ group work & 1.463 & $1.156-1.852$ & 1.236 & $0.734-2.082$ \\
\hline $\mathrm{R}$ information processing & 1.469 & $1.070-2.015$ & 2.279 & $1.148-4.524$ \\
\hline R ICT & 0.925 & $0.715-1.197$ & 1.149 & $0.747-1.767$ \\
\hline$R$ verbal communication & 0.726 & $0.590-0.839$ & 0.728 & $0.442-1.197$ \\
\hline
\end{tabular}

\section{References}

Allen, J., \& Le, H. (2007). An additional measure of overall effect size for logistic regression models. Journal of Educational and Behavioral Statistics, 2007, pp. 1-26.

Bandura, A. (1997). Self-efficacy: The exercise of control. New York: Cambridge University Press.

Barrie, S. C. (2006). Understanding what we mean by the generic attributes of graduates. Higher Education, 51(2), 215-241.

Barrie, S. (2007). A conceptual framework for the teaching and learning of generic graduate attributes. Studies in Higher Education, 32(4), 439-458.

Boyd, S., Chalmers, A., \& Kumekawa, E. (2001). Beyond school: Final year school students' experiences of the transition to tertiary study or employment. Wellington: New Zealand Council for Educational Research.

Braxton, J. M. (Ed.). (2000). Reworking the student departure puzzle. Nashville: Vanderbilt University Press.

Braxton, J., Brier, E., \& Steele, S. (2007). Shaping retention from research to practice. Journal of College Student Retention: Research, Theory and Practice, 9(3), 377-399.

Chanock, K. (2004). Introducing students to the culture of enquiry in an arts degree. Milperra: HERDSA.

Gurin, P., Dey, E. L., Hurtado, S., \& Gurin, G. (2002). Diversity and higher education: Theory and impact on educational outcomes. Harvard Educational Review, 72, 330-366.

Harvey, L., Drew, S., \& Smith, M. (2006). The first-year experience: A literature review for the Higher Education Academy. York: Higher Education Academy.

Hurtado, S., Han, J. C., Sáenz, V. B., Espinosa, L. L., Cabrera, N. L., \& Cerna, O. S. (2007). Predicting transition and adjustment to college: Biomedical and behavioral science aspirants' and minority students' first year of college. Research in Higher Education, 48(7), 841-887.

James, B., Skillen, J., Percy, A., Tootell, H., \& Irvine, H. (2003). From integration to transformation. Paper presented at the Fifth National Language and Academic Skills Conference: Challenges, Initiatives, Evaluations and Consequences, Flinders University, Adelaide, November 2003.

Jansen, E. P. W. A., \& Bruinsma, M. (2005). Explaining achievement in higher education. Educational Research and Evaluation, 11(3), 235-252.

Jansen, E. P. W. A., \& van der Meer, J. (2007). First-year students' expectations and perceptions of readiness before they start university. In Enhancing higher education theory and scholarship. Refereed proceedings of the 30th HERDSA annual conference (pp. 275-284). Milperra: Higher Education Research and Development Society of Australasia.

Jones, J., Bonanno, H., \& Scouller, K. (2001). Staff and student roles in central and faculty-based learning support: Changing partnerships. In The fourth national language and academic skills conference: Changing identities, University of Wollongong, November 2001.

Keup, J. R., \& Stolzenberg, E. B. (2004). The 2003 Your First College Year Survey. Exploring the academic and personal experiences of first-year students. Colombia, SC: University of South Carolina. 
Kift, S. (2008). The next, great first year challenge: Sustaining, coordinating and embedding coherent institution-wide approaches to enact the FYE as 'everybody's business'. In Keynote at the Pacific rim first-year in higher education conference, Hobart, Tasmania. http://www.fyhe.qut.edu.au/past_ papers/papers08/FYHE2008/content/html/keynotes.html. Accessed 27 September 2008.

Kift, S., \& Field, R. (2009). Intentional first year curriculum design as a means of facilitating student engagement: Some exemplars. Paper presented at the Pacific Rim First-year in Higher Education Conference, Townsville, July 2009. http://www.fyhe.qut.edu.au/past_papers/papers09/content/ pdf/16D.pdf. Accessed 3 August 2008.

Krause, K. (2005). Serious thoughts about dropping out in first year: Trends, patterns and implications for higher education. Studies in Learning, Evaluation. Innovation and Development, 2(3), 55-68.

Kuh, G., Cruce, T., Shoup, R., Kinzie, J., \& Gonyea, R. (2008). Unmasking the effects of student engagement on first-year college grades and persistence. The Journal of Higher Education, 79(5), 540-563.

Lisbon European Council: Presidency conclusions. (2000). http://www.europarl.europa.eu/summits/ lis1_en.htm. Retrieved 8 September 2008.

McInnis, C., \& James, R. (2004). Access and retention in Australian higher education. In M. Yorke \& B. Longden (Eds.), Retention and student success in higher education. Berkshire: Open University Press.

McInnis, C., James, R., \& Hartley, R. (2000). Trends in the first year experience. Canberra: Department of Education, Training and Youth Affairs.

Nicholson, N. (1999). The transition cycle: Causes, outcomes, processes and forms. In S. Fisher \& C. L. Cooper (Eds.), On the move: The psychology of change and transition. Chichester: Wiley.

Nora, A., Barlow, L., \& Crisp, G. (2005). Student persistence and degree attainment beyond the first year in college. In A. Seidman (Ed.), College student retention: Formula for success (pp. 129-153). Westport: Praeger Publications.

OECD. (2008). Education at a glance: OECD indicators.

Ozga, J., \& Sukhnandan, L. (1998). Undergraduate non-completion: Developing an explanatory model. Higher Education Quarterly, 52(3), 316-333.

Pajares, F. (1996). Self-efficacy beliefs in academic settings. Review of Educational Research, 66, 543-578.

Pascarella, E. T., Duby, P., \& Iverson, B. (1983). A test and a reconceptualization of a theoretical model of college withdrawal in a commuter institution setting. Sociology of Education, 56, 88-100.

Peng, C. J., Lee, K. L., \& Ingersoll, G. M. (2002). An introduction to logistic regression analysis and reporting. The Journal of Educational Research, 96(1), 3-14.

Press, S. J., \& Wilson, S. (1978). Choosing between logistic regression and discriminant analysis. Journal of the American Statistical Association, 7, 699-705.

Quinn, P., \& Hemmings, B. (1999). The role of personal and environmental factors in predicting persistence and satisfaction in tertiary agricultural study. Paper presented at the Australian Association for Research in Education Conference: Global Issues and Local Effects: The Challenge for Educational Research, Melbourne, 27 Nov-2 Dec 1999.

Rosenthal, J. A. (1996). Qualitative descriptors of strength of association and effect size. Journal of Social Service Research, 21(4), 37-59.

Ross, S., \& Gray, J. (2005). Transitions and re-engagement through second chance education. The Australian Educational Researcher, 32(3), 103-140.

Sieben, I. (2001) Logistische regressie-analyse: een handleiding [A guide to logistic regression analysis], University of Nijmgen, RTOG. http://www.ru.nl/socialewetenschappen/rtog/naslagwerk/ onderdelen/logistische/. Accessed 24 July 2009.

Skillen, J., Merten, M., Trivett, N., \& Percy, A. (1998). The IDEALL approach to learning development: A model for fostering improved literacy and learning outcomes for students. In Australian Association for Research in Education annual conference, Adelaide.

Smith, J. S., \& Wertlieb, E. C. (2005). Do first-year college students' expectations align with their firstyear experience? NASPA Journal, 42(2), 153-174.

Tabachnick, B. G., \& Fidell, L. S. (2007). Using multivariate statistics. Boston, MA: Pearson/Allyn and Bacon.

Taylor, J. A., \& Bedford, T. (2004). Staff perceptions of factors related to non-completion in higher education. Studies in Higher Education, 29(3), 375-394.

Tinto, V. (1987). Leaving college: Rethinking the causes and cures of student attrition. Chicago: University of Chicago Press. 
Tinto, V. (2006). Research and practice of student retention: What next? Journal of College Student Retention: Research, Theory and Practice, 8(1), 1-19.

Tweede Fase Adviespunt (2005). Met een tweede fase-diploma naar het hoger onderwijs. Deelonderzoek: Ervaringen en opvattingen van opleiders in het hoger onderwijs [With a renewed higher secondary school diploma into higher education: Higher education teachers' experiences and opinions] http://www.tweedefase-loket.nl/doc/evaluatie/met $\% 20$ een $\% 202 \mathrm{e} \% 20 \mathrm{fase}-$ diploma\%20naar\%20het\%20ho.pdf.

van der Meer, J. (2008). Mapping first semester challenges: First-year students making sense of their teaching and learning environments. Unpublished thesis, University of Otago. Dunedin.

van der Meer, J., \& Jansen, E. (2008). An international comparative study on first-year students' expectations and self-perceived readiness. Paper presented at the 30th Annual EAIR forum Copenhagen.

van der Meer, J., \& Scott, C. (2008). Shifting the balance: From teacher instruction to peer-learning primacy. The Australasian Journal of Peer Learning, 1(1), 70-79.

van Os, W. (2008). Why students leave. Paper presented at the 30th Annual EAIR forum, Copenhagen.

Watson, G., Johnson, G., \& Billett, S. (2002). Ready or not? Results of an orientation week survey of education students. Paper presented at the 6th Pacific Rim Conference First Year in Higher Education, Christchurch.

Weiner, B. (1985). An attributional theory of achievement motivation and emotion. Psychological Review, 92, 548-573.

Yorke, M. (1999). Leaving early: Undergraduate non-completion in higher education. London: Falmer Press.

Yorke, M., \& Longden, B. (2004). Retention and student success in higher education. Maidenhead: SRHE and Open University Press.

\section{Author Biographies}

Ellen P. W. A. Jansen $(\mathrm{PhD})$ is associate professor and head of the department of Higher Education at the University Centre for Learning and Teaching, University of Groningen, The Netherlands. Her main research interest is in determinants of quality in higher education, with a special focus on transition processes into and in higher education.

Jacques van der Meer $(\mathrm{PhD})$ is Associate Dean (Academic) at the University of Otago College of Education, P.O. Box 56, Dunedin, New Zealand. His interest is in the area of first-year experience, retention and peer-learning opportunities. 